\title{
Protamine-stabilized RNA as an ex vivo stimulant of primary human dendritic cell subsets
}

\author{
Annette E. Sköld ${ }^{1,2}$ • Jasper J. P. van Beek ${ }^{1}$ Simone P. Sittig ${ }^{1} \cdot$ Ghaith Bakdash $^{1}$ • \\ Jurjen Tel $^{1}$ - Gerty Schreibelt ${ }^{1}$ I. Jolanda M. de Vries ${ }^{1,3}$
}

Received: 31 October 2014 / Accepted: 21 July 2015 / Published online: 15 August 2015

(C) The Author(s) 2015. This article is published with open access at Springerlink.com

\begin{abstract}
Dendritic cells (DCs) are key in connecting innate and adaptive immunity. Their potential in inducing specific immune responses has made them interesting targets for immunotherapeutic approaches. Our research group was the first to exploit the naturally occurring myeloid DCs (mDCs) and plasmacytoid DCs (pDCs) in therapeutic vaccination trials against melanoma. To develop primary DC subsets as an optimal vaccine, the identification of a clinically applicable adjuvant activating both subsets is required. Although the expression of pathogen recognition receptors differs distinctly between the DC subsets, both pDCs and $\mathrm{mDCs}$ can respond to single-stranded RNA (ssRNA) via Toll-like receptors 7 and 8, respectively. Since ssRNA is easily degraded by RNases, we stabilized anionic RNA by complexing it with the positively charged protein protamine. This leads to the formation of protamine-RNA complexes with varying features depending on ionic content. We subsequently investigated the immunostimulatory effect of complexes that formed various salt concentrations on purified DC subsets. Both mDCs and pDCs upregulated
\end{abstract}

Electronic supplementary material The online version of this article (doi:10.1007/s00262-015-1746-9) contains supplementary material, which is available to authorized users.

I. Jolanda M. de Vries

Jolanda.deVries@radboudumc.nl

1 Department of Tumor Immunology, Radboud Institute for Molecular Life Sciences, Radboud University Medical Centre, Nijmegen, The Netherlands

2 Department of Oncology-Pathology, Karolinska University Hospital Solna, Karolinska Institutet, Stockholm, Sweden

3 Department of Medical Oncology, Radboud University Medical Centre, Geert Grooteplein 26, Route 278, 6525 GA Nijmegen, The Netherlands maturation markers and produced pro-inflammatory cytokines in a dose-dependent way to the protamine-RNA complexes. This was dependent on endosomal acidification and correlated partly with the uptake of protamineRNA complexes. Furthermore, both DC subsets induced T cell proliferation and IFN gamma secretion in a beneficial ratio to $\mathrm{IL}-10$. These results indicate that protamine-RNA complexes can be used to stimulate human $\mathrm{mDC}$ and $\mathrm{pDC}$ ex vivo for use in immunotherapeutic settings.

Keywords Immunotherapy $\cdot \mathrm{pDC} \cdot \mathrm{mDC} \cdot \mathrm{TLR}$.

Adjuvants · GMP

$\begin{array}{ll}\text { Abbreviations } \\ \text { CCR7 } & \text { C-C chemokine receptor type 7 } \\ \text { CFSE } & \text { Carboxyfluorescein diacetate succinimidyl ester } \\ \text { CTL } & \text { Cytotoxic CD8 }{ }^{+} \text {T cell } \\ \text { DC } & \text { Dendritic cell } \\ \text { FSME } & \text { Frühsommer-meningoencephalitis } \\ \text { GMP } & \text { Good manufactoring practice } \\ \text { HLA } & \text { Human leukocyte antigen } \\ \text { IFN } & \text { Interferon } \\ \text { IL } & \text { Interleukin } \\ \text { MFI } & \text { Mean fluorescence intensity } \\ \text { MHC } & \text { Major histocompatibility complex } \\ \text { MLR } & \text { Mixed lymphocyte reaction } \\ \text { mAb } & \text { Monoclonal antibody } \\ \text { mDC } & \text { Myeloid DC } \\ \text { PBL } & \text { Peripheral blood leukocyte } \\ \text { PBMC } & \text { Peripheral blood mononuclear cell } \\ \text { pDC } & \text { Plasmacytoid DC } \\ \text { poly I:C } & \text { Polyinosine-polycytidylic acid } \\ \text { pR } & \text { Protamine-RNA complex } \\ \text { PRR } & \text { Pattern recognition receptor } \\ \text { SEB } & \text { Staphylococcal enterotoxin B }\end{array}$




$\begin{array}{ll}\text { ssRNA } & \text { Single-stranded RNA } \\ \text { TCR } & \text { T cell receptor } \\ \text { Th } & \text { T helper } \\ \text { TLR } & \text { Toll-like receptor } \\ \text { TNF } & \text { Tumor necrosis factor }\end{array}$

\section{Introduction}

Dendritic cells (DCs) connect the innate and the adaptive immune systems. In blood, three major DC subsets are found: $\mathrm{CD} 1 \mathrm{c}^{+}\left(\mathrm{BDCA}^{+}\right)$myeloid DCs $(\mathrm{mDCs}), \mathrm{CD} 141^{+}$ $\left(\mathrm{BDCA}^{+}\right) \mathrm{mDCs}$, and $\mathrm{CD} 303\left(\mathrm{BDCA}^{+}\right)$plasmacytoid DCs (pDCs) [1, 2]. After a DC has encountered an antigen, it matures and migrates to the adjacent lymph node, where it interacts with naïve $\mathrm{T}$ cells and initiates an antigen-specific immune response. The activation state of the DCs will influence the resulting adaptive response, spanning from tolerogenic to immunogenic [3]. To sense danger and to be able to initiate eradicating adaptive responses against antigens, DCs are equipped with a wide range of pattern recognition receptors (PRRs) [4]. These receptors recognize danger-associated molecular patterns, such as conserved microbial structures or nucleic acids, which upon binding mature the DCs. The types of PRRs being engaged on the DCs have a great impact on the subsequent adaptive immune response.

There are several groups of PRRs, the first characterized, and so far the most studied group, are the Toll-like receptors (TLRs) [5]. These are transmembrane molecules expressed in hetero- or homodimers, either on the cell surface or in the endosomal compartment. Most innate immune cells express TLRs in various combinations, and the receptor family therefore poses as potential target for vaccine adjuvants. In addition to the naturally occurring ligands, several synthetic TLR ligand analogs have been developed.

Due to their unique ability to stimulate naïve $\mathrm{T}$ cells, DCs are often used in cell-based immunotherapy. The majority of DC-based clinical studies are performed with in vitro differentiated DCs, such as monocyte-derived DCs or cells generated from $\mathrm{CD}_{3} 4^{+}$progenitor cells [6-8]. Our research group is using pDCs [9] and $\mathrm{CD} 1 \mathrm{c}^{+}$DCs (Schreibelt et al. manuscript in preparation) in therapeutic vaccination of melanoma patients, with promising results [9]. However, the stimuli used to mature these subsets are not purified PRR ligands, which are required for optimal activation of DCs [3]. Activation of PRRs such as TLRs will upregulate major histocompatibility complex (MHC) molecules, co-stimulatory molecules, and prime DCs to produce $\mathrm{T}$ helper (Th) polarizing cytokines. These cytokines act on interacting antigen-specific $\mathrm{T}$ cells and skew the adaptive immune response toward a desirable phenotype, depending on initial stimuli [10]. The usage of strong DC activators, such as TLR ligands, as adjuvant in immunotherapy is therefore desirable.

For effective anti-tumor effects, a Th1 response with the ability to activate cytotoxic $\mathrm{CD} 8^{+} \mathrm{T}$ cells (CTLs) is required. This is induced by interleukin (IL) 12p70-producing DCs, but can also be mediated by type I interferons (IFNs) $[11,12]$. An inducer of IL-12p70 in mDCs is the TLR3 ligand poly I:C, while pDCs are secreting high levels of IFN- $\alpha$ in response to TLR9-activating $\mathrm{CpG}$ oligonucleotides [13]. However, $\mathrm{CpG}$ has been shown to inhibit the effect of poly I:C, and using a combination of these two ligands in an adjuvant would most likely not be beneficial [14]. Instead, to prevent unforeseen cross-reactions, a stimulus with the potency to activate both $\mathrm{mDCs}$ and pDCs is preferred. Additionally, a standardized protocol would also provide more flexibility in combining the two subsets in future studies and clinical trials. Cross-talk between mDCs and pDCs has been shown to be important both in anti-viral responses and during anti-cancer immunotherapy [15]. We hypothesize that using both subsets will result in a broader and multifaceted immune reaction in response to DC-based immunotherapy.

One obstacle for using one stimulus for both DC subsets is that they do not express an overlapping repertoire of TLRs [13]. However, TLR7 and TLR8, expressed by pDCs and mDCs, respectively, can respond to the same type of ligand-single-stranded RNA (ssRNA) [5, 16]. Unprotected ssRNA is a suboptimal ex vivo DC stimulator due to its sensitivity to RNases, RNA-degenerating enzymes present in, e.g., serum [17]. So far, there is no ligand targeting both TLR7 and TLR8 approved for clinical use other than topical application [18]. By using the polybasic protein protamine, ssRNA can be stabilized in an immunostimulatory protamine-RNA complex [19-21]. In this study, we have evaluated the effect of protamine-RNA complexes, consisting of clinically applicable reagents, on purified DC subsets. Both pDCs and $\mathrm{CD} 1 \mathrm{c}^{+} \mathrm{DCs}$ upregulated maturation markers and secreted pro-inflammatory cytokines upon treatment with protamine-RNA. This was dependent on endosomal maturation and the ability of the complexes to engage TLR signaling. Furthermore, protamine-RNAstimulated DCs induced $\mathrm{T}$ cell proliferation and antigenspecific $\mathrm{T}$ cell activation, making the complexes a highly interesting stimulus for future vaccination trials based on primary human DC subsets.

\section{Materials and methods}

\section{Reagents}

As ligands for TLR3, 7/8, and 9, polyinosine-polycytidylic acid (poly I:C, $20 \mu \mathrm{g} / \mathrm{ml}$; Sigma-Aldrich, St Louis, MO), 
imidazoquinoline (R848, $4 \mu \mathrm{g} / \mathrm{ml}$; Axxora, San Diego, $\mathrm{CA}$ ), and $\mathrm{CpG}$ class $\mathrm{C}$ DNA oligodeoxynucleotides (CpG, $5 \mu \mathrm{g} / \mathrm{ml}$; Axxora) were used. To inhibit endosomal acidification, chloroquine $(20 \mu \mathrm{M}$; Invivogen, Toulouse, France) was pre-incubated with the cells $1 \mathrm{~h}$ before addition of the stimulus. To capture cytokines intracellularly, brefeldin A (10 $\mu \mathrm{g} / \mathrm{ml}$; Sigma-Aldrich) was added to the cultured cells $12 \mathrm{~h}$ before analysis.

\section{Preparation of protamine-RNA complexes}

To form the protamine-RNA complexes, protamine (protaminehydrochloride MPH $5000 \mathrm{IE} / \mathrm{ml}$; Meda Pharma BV, Amstelveen, the Netherlands) was diluted to $0.5 \mathrm{mg} / \mathrm{ml}$ in water, $25 \mathrm{mM} \mathrm{NaCl}$, or $50 \mathrm{mM} \mathrm{NaCl}$ and mixed 2:1 with ca 2-kbp-long single-stranded mRNA (coding for gp100, tyrosinase, or CEA, $0.5 \mathrm{mg} / \mathrm{ml}$; CureVac $\mathrm{GmbH}$, Tübingen, Germany). After extensive mixing, the mix was incubated for 5-10 min at room temperature and added to the cell cultures in the indicated concentrations. Dynamic light scattering and zeta potential of the complexes were measured in a Malvern Zetasizer 2000 (Malvern Instruments Ltd, Malvern, UK).

For the uptake experiments, the formed complexes were diluted 1:1 in the Fixable Viability Dye eFluor 780 (livedead dye, 200X; eBioscience, San Diego, CA) and incubated at room temperature for $15 \mathrm{~min}$. The reaction was stopped by addition of $10 \%$ human serum or RNase-free bovine serum albumin and the labeled complexes were added to DCs. The DC viability was investigated by adding propidium iodide (500 ng/ml; Biolegend, San Diego, CA) just before acquisition.

\section{Cell isolation and culture}

Peripheral blood mononuclear cells (PBMCs) were isolated from buffy coats of healthy individuals taken after informed consent using Ficoll density centrifugation (Lymphoprep; Axis-Shield PoC AS, Oslo, Norway). For $\mathrm{CD}_{1}{ }^{+} \mathrm{DC}$ and $\mathrm{pDC}$ isolation from PBMCs, microbead isolation kits were used $\left(\mathrm{BDCA}^{+}{ }^{+} \mathrm{DC}\right.$ and $\mathrm{BDCA} 4^{+} \mathrm{DC}$ isolation kits; Miltenyi Biotec, Bergisch-Gladbach, Germany), resulting in up to $95 \%$ purity. During purification of $\mathrm{CD}^{+} \mathrm{c}^{+} \mathrm{DC}$, $\mathrm{CD} 14^{+}$cells were depleted using CD14 microbeads (Miltenyi Biotec). Prior pDC isolation, peripheral blood leukocytes (PBLs) were prepared by depleting monocytes from PBMCs either by plastic adherence or with CD14 microbeads. Isolated cells were cultured overnight at $5 \times 10^{5}$ cells/ $\mathrm{ml}$ in X-VIVO-15 medium (Cambrex, Verviers, Belgium) supplemented with $2 \%$ human serum (Sanquin, Nijmegen, the Netherlands). For unstimulated pDCs, recombinant human IL-3 (10 ng/ml; Cellgenix, Freiburg, Germany) was added as a survival factor. $\mathrm{T}$ cells were isolated using negative microbead selection (Miltenyi Biotec), resulting in up to $98 \%$ purity.

293XL-hTLR8 HEK cell lines (InvivoGen) expressing endosomal TLR8 were cultured in DMEM with GlutaMAX (Life Technologies, Carlsbad, CA) supplemented with $10 \%$ fetal calf serum (FCS), $1 \%$ antibiotic antimycotic (AA; PAA laboratories, Pasching, Austria), and blasticidin $(10 \mu \mathrm{g} / \mathrm{ml}$; InvivoGen) as selection antibiotic.

Jurkat E6.1 fl296 cells transfected with T cell receptor (TCR) v-beta14, as previously described [22, 23], were cultured in RPMI (Life Technologies) supplemented with $10 \% \mathrm{FCS}$ and $0.5 \%$ AA.

\section{Stimulation with protamine-RNA complexes}

All DC experiments were performed in X-VIVO-15 in the presence of $2 \%$ human serum. For DC co-culture experiments, Jurkat cells were diluted in X-VIVO-15 supplemented with $2 \%$ human serum. 293XL-hTLR8 HEK cell lines were stimulated in DMEM with GlutaMAX supplemented with $10 \%$ FCS $1 \%$ AA and blasticidin. protamine-RNA complexes were made fresh 5-10 min before addition to cell culture. R848 was used as TLR7/8 control.

\section{Flow cytometry}

The purity of freshly isolated $\mathrm{CD} 1 \mathrm{c}^{+} \mathrm{DC}$ and $\mathrm{pDC}$ was assessed by staining with the following primary monoclonal antibodies (mAbs): anti-CD19-FITC (Dako, Glostrup, Denmark), anti-BDCA1-PE, anti-BDCA-2-APC (both Miltenyi Biotec), and anti-CD14-PerCP (BD Biosciences, San Jose, CA). The purity of freshly isolated $\mathrm{T}$ cells was determined by staining with mAb anti-CD20-FITC, anti-CD3-PE, and anti-CD56-APC (all BD Biosciences). For human leukocyte antigen (HLA) phenotyping, the $\mathrm{mAb}$ anti-HLA-A2-PE (BD Biosciences) was used. The samples were acquired in a FACSCalibur (BD Biosciences).

To stain for $\mathrm{DC}$ maturation, the following $\mathrm{mAbs}$ were used: anti-HLA-ABC-PE, anti-HLA-DR-FITC, anti-CD80$\mathrm{PE}$ or PE-Cy7, anti-CD86-APC (all BD Biosciences), antiHLA-DR-PerCP (Biolegend), and anti-CD40-PE (Immunotech, Marseille, France). To stain for C-C chemokine receptor type 7 (CCR7), anti-CCR7 mouse IgG2a (R\&D Systems, Minneapolis, MN), and goat anti-mouse-IgG2aAlexa647 or Alexa488 (Life Technologies) were used. Dead cells were detected with eFluor 780 live-dead cell marker (2000X). The samples were measured on a FACSCalibur or a CyAn ADP (Beckman Coulter, Fullerton, CA).

To assess cytokine production by $\mathrm{T}$ cells after stimulation with DCs, co-cultures were stained with eFluor 780 live-dead cell marker and the following mouse mAbs: anti-CD3-PE and anti-IFN- $\gamma$-APC (all BD Biosciences) or 
anti-IgG1-APC (eBioscience) as isotype control (data not shown). Prior to IFN- $\gamma$ staining, cells were fixed and permeabilized using a cytofix/cytoperm kit (BD Biosciences). To exclude DC from the gated cell population, co-cultures were also stained with anti-BDCA2-PE-Cy7 (Biolegend) or APC (Miltenyi Biotec), and anti-CD11c-PE-Cy7. The activation of Jurkat cells was assessed with eFluor 780 livedead dye, anti-CD3-FITC, and anti-CD69-APC (both BD Biosciences). The samples were measured on a CyAn ADP.

All analyses were performed using FlowJo Software (TreeStar Inc, Ashland, OR). Only viable cells gated on the specific population in forward-side scatter were assessed. The results are depicted either as percentage positive cells or as geometric mean fluorescence intensity (MFI) normalized to the negative control to compensate for use of different flow cytometers and fluorophores.

\section{Cytokine detection}

Supernatants of stimulated cells were taken at indicated time points and analyzed with standard sandwich ELISAs detecting IL-12p70, IFN- $\gamma$ (both from Thermo Scientific, Waltham, MA), IFN- $\alpha$ (Bender Medsystems, Vienna, Austria), IL-5, IL-10 (both from eBioscience), tumor necrosis factor (TNF) $\alpha$, and IL-8 (both from BD Biosciences).

\section{Mixed lymphocyte reaction}

The ability of stimulated DCs to induce $\mathrm{T}$ cell proliferation was investigated in a mixed lymphocyte reaction (MLR). Allogeneic PBLs or $\mathrm{T}$ cells were stained with carboxyfluorescein diacetate succinimidyl ester (CFSE, $5 \mu \mathrm{M}$; Life Technologies) for $10 \mathrm{~min}$; thereafter, the reaction was stopped by protein blocking using FCS. Overnight-activated DCs were cultured with CFSE-labeled cells in a 1:10 ratio for 3-5 days. As a control, Staphylococcal enterotoxin B (SEB, $5 \mu \mathrm{g} / \mathrm{ml}$; Sigma-Aldrich) was used.

\section{Antigen-presentation assay}

Donors were screened for HLA-A0201, and DCs from positive donors were stimulated with indicated stimuli, pulsed with $10 \mu \mathrm{M}$ specific peptide $\left(\mathrm{gp}^{100_{280-288}}\right)$ or irrelevant

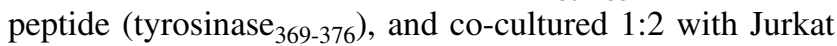
E6.1 fl296 cells expressing the TCR-v-beta14 overnight.

\section{Statistical analyses}

To detect statistical significant differences between indicated groups, Wilcoxon matched-pair signed-rank tests or $t$ tests were performed on raw data and paired measurements and analyzed with GraphPad Prism (GraphPad, La Jolla, CA). Values of $p<0.05$ were considered significant.

\section{Results}

\section{Protamine complexed with RNA forms positively charged particles with varying size depending on salt concentration}

It has long been known that negatively charged RNA has the ability to bind strongly to substances with positive charge [24]. A protein that has been used to complex nucleic acids is the polybasic protein protamine [17, 21 , 25]. The physical characteristics of complexes formed when mixing anionic RNA to cationic protamine is dependent on the ratio between the components and on ionic content [26]. Since CD1c ${ }^{+}$DCs and pDCs differ in their ability to take up and respond to particles [27] and express different TLRs [4], we produced protamine-RNA complexes in a ratio of $2: 1$ in 0,25 , or $50 \mathrm{mM} \mathrm{NaCl}$ and investigated their size by dynamic light scattering (Fig. 1a-b). The complexes formed in water or low salt concentration were $<200 \mathrm{~nm}$ in diameter, while higher salt concentration formed complexes of $>500 \mathrm{~nm}$. The particle charge remained relatively constant between the formulations, ranging between 30 and $40 \mathrm{mV}$ (Fig. 1c).

\section{Protamine-RNA complexes mature both $\mathrm{CD}^{+} \mathrm{c}^{+} \mathrm{DCs}$ and $\mathrm{pDCs}$ in a concentration-dependent manner}

To evaluate the ability of RNA complexed to protamine to activate DCs, we formulated protamine-RNA complexes with different salt conditions (Fig. 2). Purified DCs were cultured overnight with concentrations ranging from 1.5 to $15 \mu \mathrm{g} / \mathrm{ml}$ of protamine-RNA complexes formed in either 0 , 25 , or $50 \mathrm{mM} \mathrm{NaCl}$. As a control for cell stimulation, the TLR7/8 ligand R848 was used. Viability and expression of maturation markers were investigated. Unstimulated pDCs do not survive ex vivo; therefore, IL-3-treated cells were used as a negative control [28].

The viability of the CD1 $\mathrm{c}^{+}$DCs was not affected by protamine-RNA complexes, while a slight decrease in viability was detected for pDCs (Fig. 2a). To investigate whether protamine-RNA complexes had a direct toxic effect on the pDCs, IL-3 was added to the cultures and the viability examined. There was no difference in viability between R848-treated pDCs and protamine-RNA-treated pDCs. IL-3 had a favorable effect on pDC viability in the tested conditions (Supplementary Fig. 1a).

Next, the ability of the protamine-RNA complexes to mature DCs was investigated. For the CD1c DCs, all complexes increased the expression of MHC class I, while only smaller complexes had this effect on pDCs (Fig. 2b). Protamine-RNA-induced upregulation of HLA-DR was detected on the $\mathrm{CD} 1 \mathrm{c}^{+}$DCs, while on the pDCs, IL-3 alone 


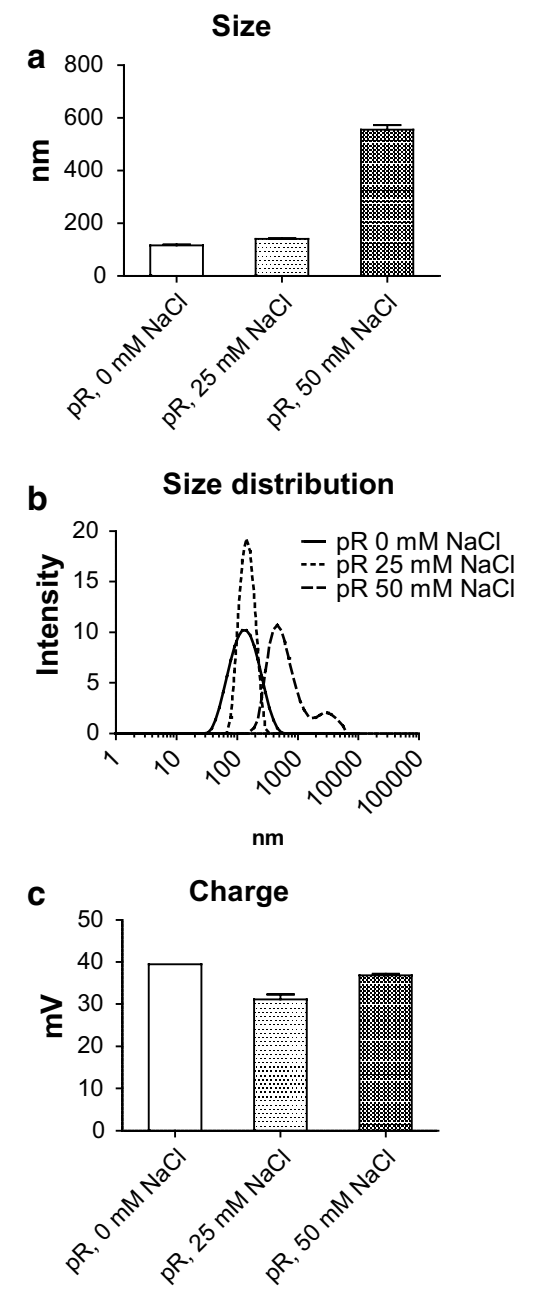

Fig. 1 Concentration of $\mathrm{NaCl}$ determines size, but not charge, when forming protamine-RNA complexes. protamine-RNA complexes (pR) were formed in water, $25 \mathrm{mM} \mathrm{NaCl}$, or $50 \mathrm{mM} \mathrm{NaCl}$, particle size was evaluated by dynamic light scattering $(\mathbf{a}, \mathbf{b})$, and the zeta potential was investigated to determine the charge of the complexes (c)

increased HLA-DR expression and no additive effect of the complexes was observed. All complexes induced upregulation of maturation marker CD86 on $\mathrm{CD} 1 \mathrm{c}^{+} \mathrm{DCs}$, with the strongest effect detected for the large complexes formed in the presence of high salt concentrations (Fig. 2c). For the pDCs, an opposite pattern was seen; the highest upregulation of CD86 was induced by protamine-RNA complexes formed without salt (Fig. 2c).

Since the viability of the DCs did not differ between the protamine-RNA concentrations used and a dose-dependent upregulation of maturation markers and MHC complexes was observed, we performed additional experiments with the highest concentration tested. This concentration also led to upregulation of additional activation markers, such as CD40, CD80, and CCR7 (Supplementary Fig. 1b, c). Unprotected RNA has previously been shown to activate an antigen-specific immune response upon intranodal injection [29]. However, addition of RNA or protamine without complexing did not lead to DC maturation in our hands (data not shown).

\section{Dendritic cells stimulated with protamine-RNA complexes release high levels of pro-inflammatory cytokines}

The cytokine profile of activated DCs plays an important role in the skewing of naïve $\mathrm{T}$ cells. We therefore compared the release of pro-inflammatory cytokines from purified DCs stimulated overnight with protamine-RNA complexes formed in water or increasing salt concentrations. All three protamine-RNA complex formations induced fivefold to tenfold more IL-12p70 than the positive control poly I:C (Fig. 3a). pDCs secreted comparable levels of IFN- $\alpha$ upon stimulation with the positive control $\mathrm{CpG}-\mathrm{C}$ and protamine-RNA complexes (Fig. 3b). In accordance with the results in Fig. 2, the smaller protamine-RNA complexes induced the strongest response in pDCs.

An important regulator of IL-12 production is IL-10 [30]. IL-10 production by both $\mathrm{CD} 1 \mathrm{c}^{+} \mathrm{DCs}$ and pDCs was observed after stimulation with poly I:C and $\mathrm{CpG}-$ C, respectively. Significantly lower amounts of IL-10 were observed in the protamine-RNA-stimulated cultures (Fig. 3c). Both DC subsets secreted significant amounts of TNF- $\alpha$ upon protamine-RNA treatment (Fig. $3 \mathrm{c}$ ).

\section{Protamine-RNA complexes induce TLR signaling via the endosomal compartment of DCs}

When investigating the cytokine profile of protamineRNA-stimulated DCs, a shift toward NFKB-driven responses was seen with increasing salt concentrations, while a type I IFN response was seen when the complexes were formed in water. We therefore investigated what mechanism was driving the DC responses. The activation via TLR7 in response to protamine-RNA complexes is previously shown in a murine setting [20],

We confirmed that the complexes had the ability to signal via TLRs by testing the effect of the complexes on TLR8expressing HEK cells. TLR8-expressing or non-transduced HEK cells were cultured overnight with the different protamine-RNA complexes, and IL-8 was measured in the supernatant. While no IL-8 was secreted from TLR8 non-expressing cells (data not shown), all protamine-RNA complexes were able to induce IL-8 production in TLR8-expressing HEK cells, with the complexes formed with high salt concentrations inducing the highest response (Fig. 4a).

To activate TLR7/8, the ligand should reach the endosomes, where signaling is initiated by lowering the $\mathrm{pH}$. To study the binding and uptake of protamine-RNA 
a

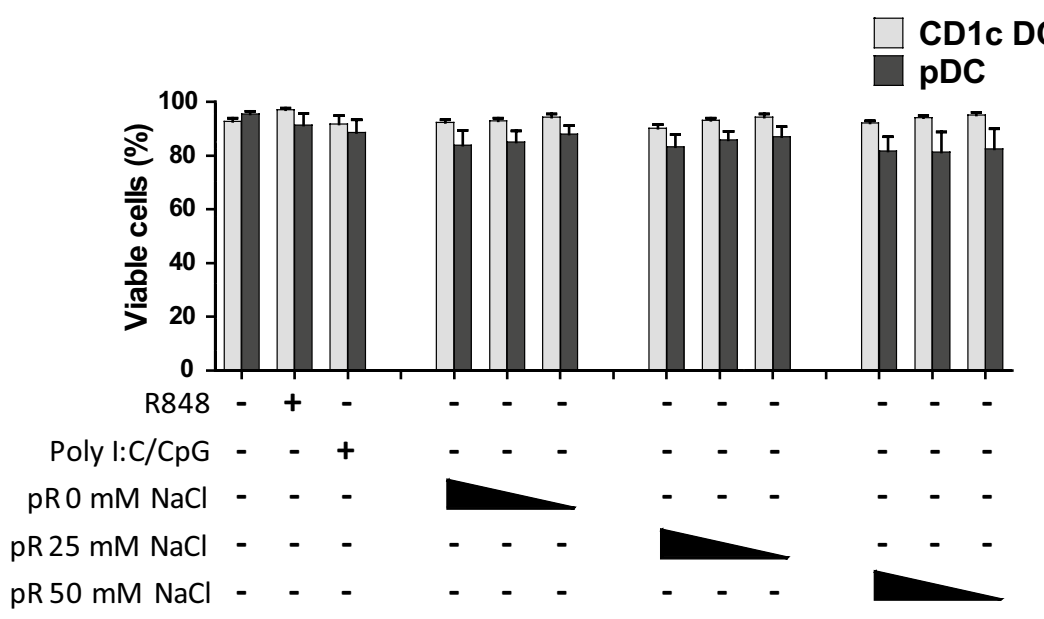

b

$\mathrm{CD}^{+} \mathrm{C}^{+} \mathrm{DC}$
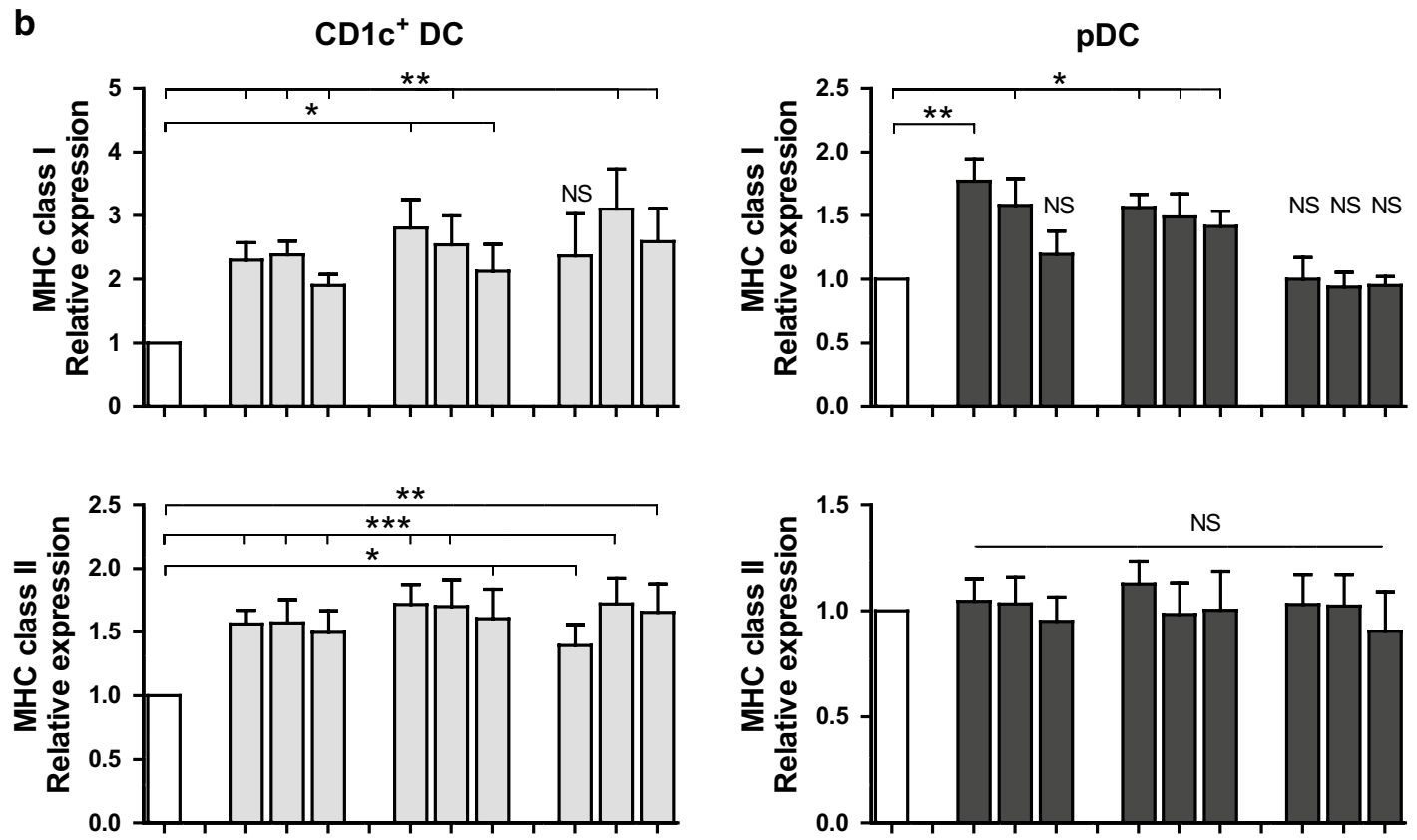

$\mathrm{pRO} \mathrm{mM} \mathrm{NaCl}-$ $\mathrm{pR} 25 \mathrm{mM} \mathrm{NaCl}$ -

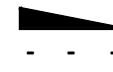

- - $\quad$ pRO $\mathrm{mM} \mathrm{NaCl}$ pR $50 \mathrm{mM} \mathrm{NaCl}$ -

c

$\mathrm{CD}^{+} \mathrm{c}^{+} \mathrm{DC}$

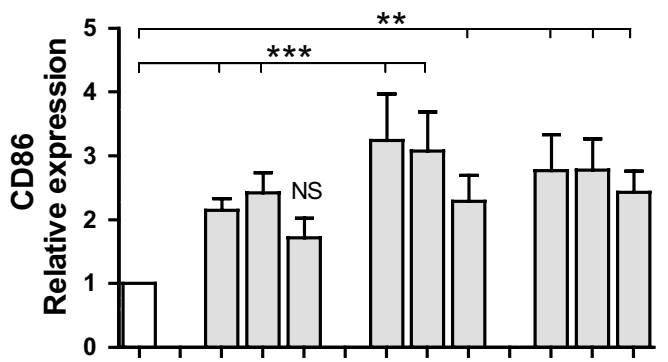

$\mathrm{R} 25 \mathrm{mM} \mathrm{NaCl}$ -
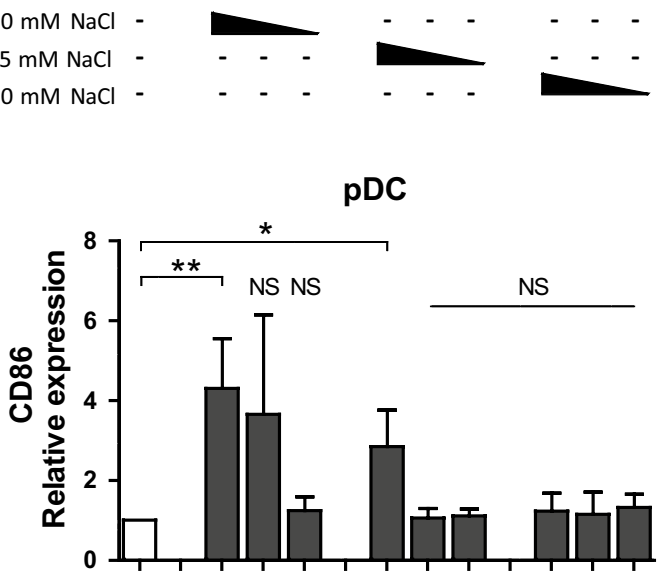

$\mathrm{pRO} \mathrm{mM} \mathrm{NaCl}$ pR $25 \mathrm{mM} \mathrm{NaCl}$ pR $50 \mathrm{mM} \mathrm{NaCl}$ -

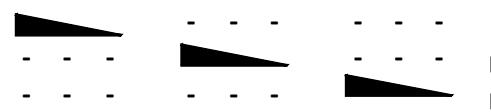

$\mathrm{pRO} \mathrm{mM} \mathrm{NaCl}-$ pR25 mM NaCl pR $50 \mathrm{mM} \mathrm{NaCl}$ - 
4Fig. 2 Protamine-RNA complexes are well tolerated by DCs and induce upregulation of maturation markers and MHC complexes. Purified CD1c ${ }^{+}$DCs and pDCs were cultured $18-24 \mathrm{~h}$ with $15,7.5$, or $1.5 \mu \mathrm{g} / \mathrm{ml}$ of protamine-RNA complexes (pR) formed in 0,25 , or $50 \mathrm{mM} \mathrm{NaCl}$. Untreated CD1c ${ }^{+}$DCs or IL-3 treated pDCs were used as negative controls, while R848 was used as a control for TLR7/8 stimulation and poly I:C and $\mathrm{CpG}-\mathrm{C}$ were used as positive controls for $\mathrm{CD} 1 \mathrm{c}^{+} \mathrm{DCs}$ or $\mathrm{pDCs}$, respectively. a The cell viability was determined by flow cytometry. The mean percentage \pm SEM of cells negative for live-dead marker from 7-8 CD1c ${ }^{+}$DC donors and 6-8 pDC donors is depicted. b, c The relative expression of MHC class I and HLA-DR (b) and CD86 (c) on viable cells was calculated by normalizing the MFI values for each donor against the negative control. The fold increase \pm SEM of $6-10 \mathrm{CD} 1 \mathrm{c}^{+} \mathrm{DC}$ and $\mathrm{pDC}$ donors is depicted. Wilcoxon matched-pair signed-rank tests were performed on raw data, comparing against negative control, and are indicated by $*(p<0.05), * *(p<0.01), * * *(p<0.001)$, or NS (non-significant)

complexes by DCs, protamine-RNA complexes were incubated with a fixable live-dead dye. This dye binds nucleic acids, and its activity can be stopped by addition of a protein blocker. Protamine-RNA complexes labeled with the live-dead dye, the live-dead dye alone, or medium alone were added to $\mathrm{CD} 1 \mathrm{c}^{+}$DCs and pDCs. After culturing for $1 \mathrm{~h}$, the binding and uptake was assessed by flow cytometry (Fig. 4b, c). In some experiments, propidium iodide was used as a viability stain to confirm that the labeled complexes were bound to viable DCs (data not shown). Approximately $15 \%$ of the CD1c ${ }^{+}$DCs associated with labeled complexes after $1 \mathrm{~h}$ of culture. For pDCs, the smallest complexes were most efficiently bound, although also the larger complexes formed in high $\mathrm{NaCl}$ concentrations associated stronger with pDCs as compared to CD1c ${ }^{+}$DCs.

Next, we investigated the importance of endosomal maturation for protamine-RNA-induced DC activation. Endosomal acidification was prevented using chloroquine $1 \mathrm{~h}$ before addition of the complexes. The TLR ligands poly $\mathrm{I}: \mathrm{C}$ and $\mathrm{CpG}-\mathrm{C}$ were used as controls for the efficacy of chloroquine treatment, while R848, previously shown to be able to induce DC activation despite chloroquine treatment [31], was used as a positive control. The increase in CD86 and CD80 expression was inhibited when the chloroquine pre-treated DCs were cultured with the complexes, as compared to untreated cells (Fig. 4d and Supplementary Fig. 2a). The secretion of IL-12p70 and IFN- $\alpha$ was absent in chloroquine-treated $\mathrm{CD} 1 \mathrm{c}^{+} \mathrm{DCs}$ and $\mathrm{pDCs}$, respectively, as well as TNF- $\alpha$ (Supplementary Fig. 2b). Although the viability of the $\mathrm{CD} 1 \mathrm{c}^{+}$DCs was not strongly affected by the addition of chloroquine, pDCs were deprived of their survival signal and a decreased viability was seen in all groups except for the IL-3- or R848-treated cells (Supplementary
Fig. 3 Pro-inflammatory cytokines are secreted by protamine-RNA-stimulated DCs. The concentrations of pro-inflammatory cytokines in supernatants taken from CD1c ${ }^{+}$ DCs and pDCs stimulated overnight with medium or IL-3, R848, poly I:C or CpG-C, or $15 \mu \mathrm{g} / \mathrm{ml}$ protamine-RNA complexes (pR) formed in 0,25 , or $50 \mathrm{mM} \mathrm{NaCl}$ were measured by ELISA. The concentration \pm SEM of IL-12p70 (a) from 9 to $11 \mathrm{CD}^{\mathrm{c}} \mathrm{c}^{+} \mathrm{DC}$ donors, IFN- $\alpha$ (b) from 6-10 $\mathrm{pDC}$ donors, or IL-10 and TNF- $\alpha$ (c) from 5-11 CD1c ${ }^{+} \mathrm{DC}$ and 4-8 pDC donors is depicted. Wilcoxon matched-pair signedrank tests were performed between indicated groups and are indicated by $*(p<0.05)$, $* *(p<0.01)$, or $* * *(p<0.001)$ a

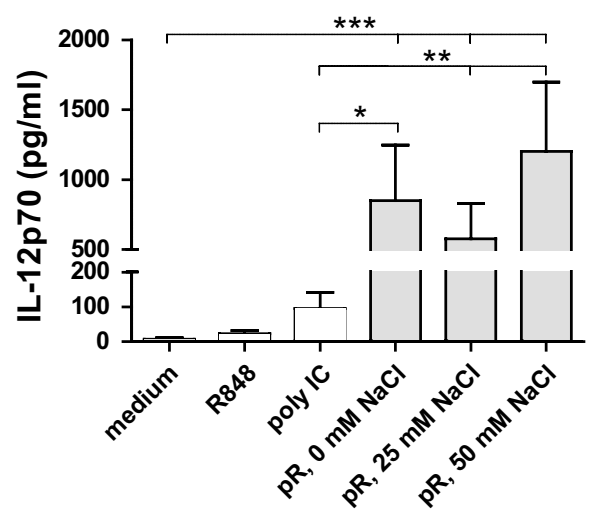

C

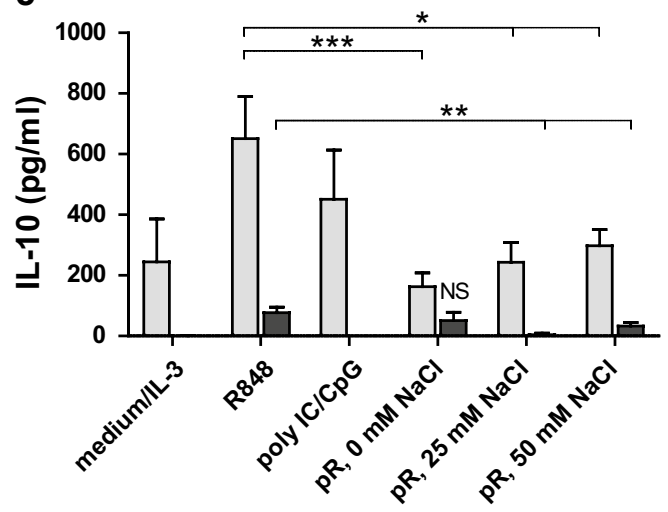

b
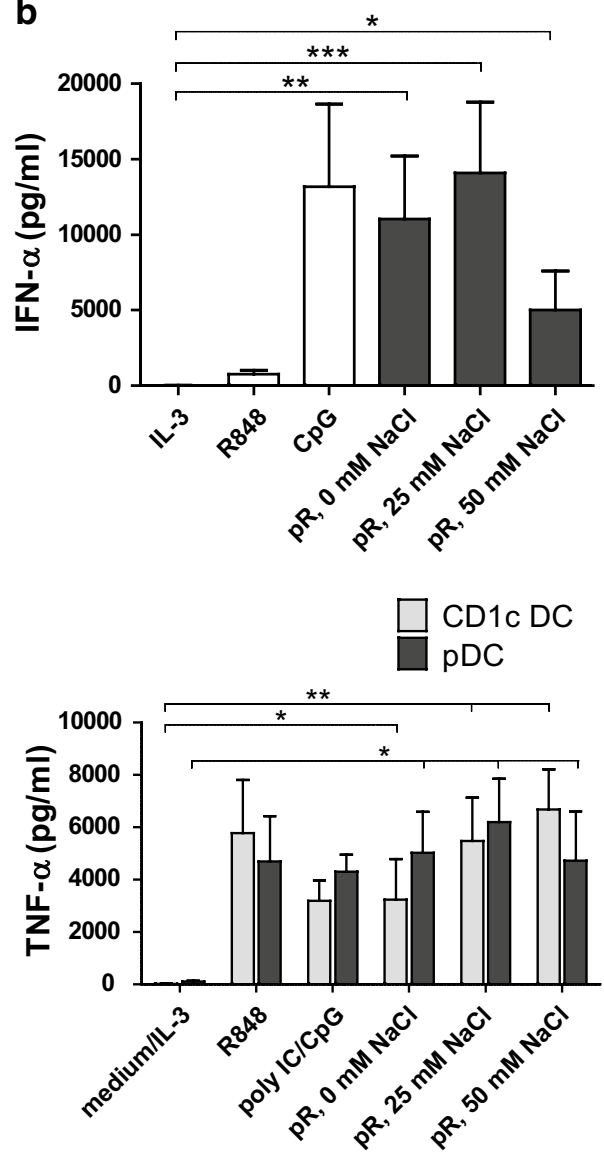
Fig. 4 Effect of protamineRNA complexes is TLR mediated. a TLR8 expressing HEK cells were cultured overnight with medium alone, R848, or protamine-RNA complexes (pR) formed in 0,25 , or $50 \mathrm{mM}$ $\mathrm{NaCl}$. The mean results \pm SEM from three individual experiments run in triplicate or duplicate is depicted. $T$ tests were performed on pooled data between indicated groups and are indicated by $*(p<0.05)$ or NS (non-significant). (b-c) DCs were cultured for $1 \mathrm{~h}$ with livedead marker-labeled protamineRNA complexes (pR) formed in 0,25 , or $50 \mathrm{mM} \mathrm{NaCl}$ or with live-dead marker alone and analyzed by flow cytometry. Percentages of protamine-RNApositive cells were calculated on gated DCs and depicted as a representative figure (b) or as the mean uptake \pm SEM from 7 $\mathrm{CD}_{\mathrm{c}}{ }^{+} \mathrm{DC}$ and $\mathrm{pDC}$ donors (c). Wilcoxon matched-pair signedrank tests were performed between indicated groups and are indicated by $*(p<0.05)$ or $* *(p<0.01)$. d CD1c $c^{+}$DCs and pDCs were pre-incubated for $1 \mathrm{~h}$ with chloroquine before the addition of medium alone or IL-3, R848, poly I:C or CpG-C, or protamine-RNA complexes (pR) formed in 0,25 , or $50 \mathrm{mM} \mathrm{NaCl}$. The upregulation of CD86 was measured by flow cytometry after overnight culture and the relative expression was calculated by normalizing the MFI values for each donor against the negative control. Fold increase \pm SEM of 4-5 CD1c ${ }^{+}$DC and 3-5 pDC donors is depicted. $T$ tests were performed on raw data between indicated groups and are indicated by $*(p<0.05)$, $* *(p<0.01), * * *(p<0.001)$, or NS (non-significant)
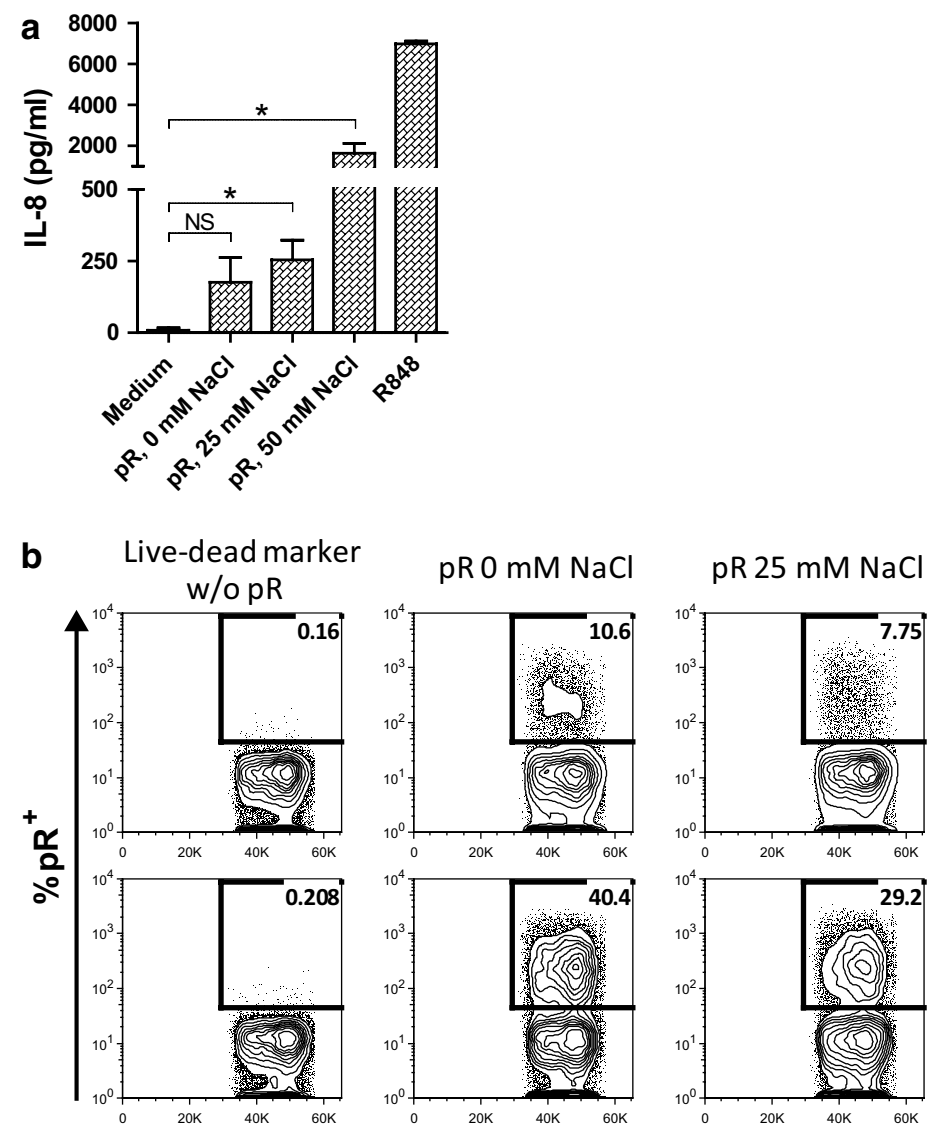

pR $50 \mathrm{mM} \mathrm{NaCl}$

C
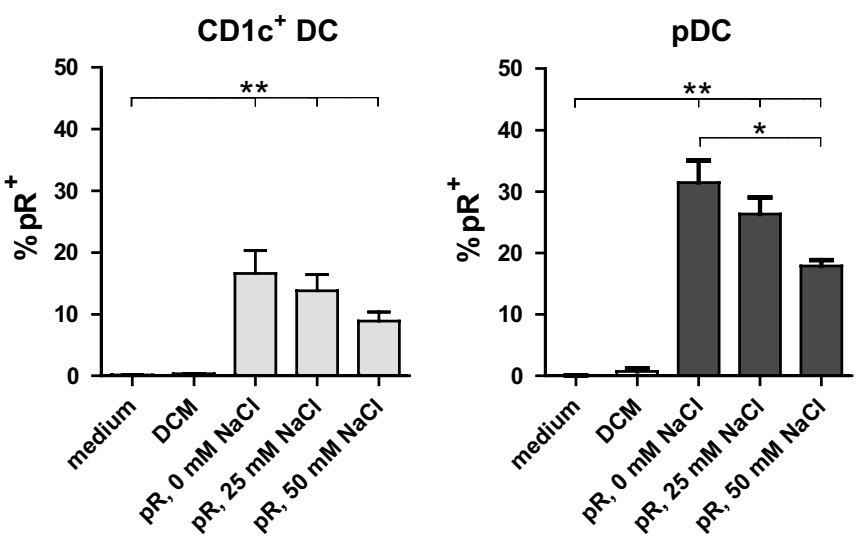

d

$\mathrm{CD}^{+} \mathrm{C}^{+} \mathrm{DC}$
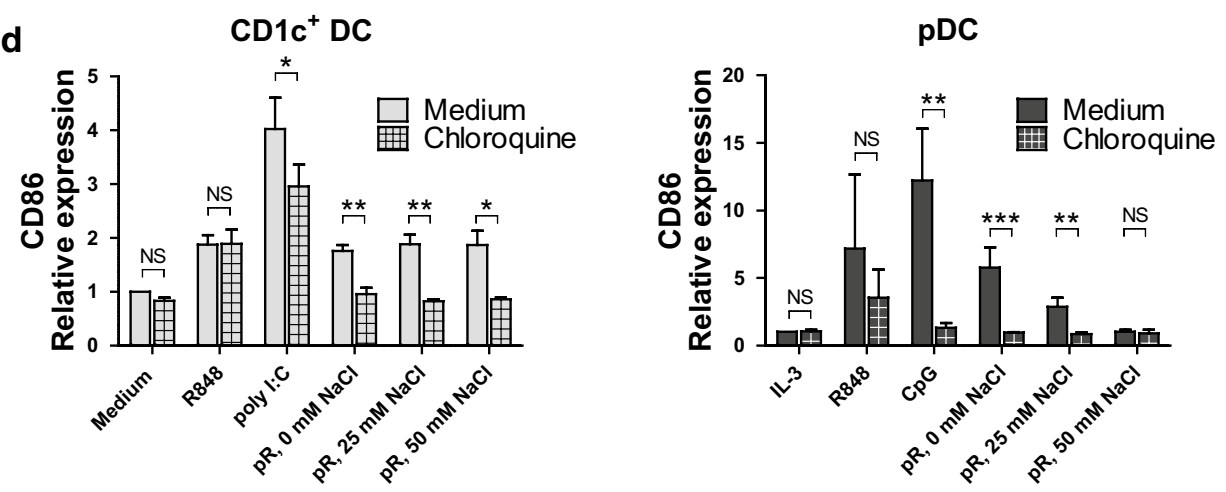
Fig. $5 \mathrm{~T}$ cell proliferation and IFN- $\gamma$ production is induced by protamine-RNA-stimulated DCs. DCs were cultured with medium alone or IL-3, R848, or protamine-RNA complexes (pR) formed in 0,25 , or $50 \mathrm{mM}$ $\mathrm{NaCl}$. CFSE-labeled allogenic PBLs or T cells were added after overnight culture. a The dilution of CFSE-labeled PBLs was measured on $\mathrm{CD}^{+} \mathrm{CD} 11 \mathrm{c}^{-} \mathrm{BDCA}^{-}$cells by flow cytometry on day 5 . Cultured, unstimulated PBLs were used as reference. The mean percentage proliferating cells \pm SEM of $6 \mathrm{CD}^{+} \mathrm{c}^{+} \mathrm{DC}$ and $\mathrm{pDC}$ donors is depicted. b The expression of IFN- $\gamma$ and IL-10 in day 2 DC:PBL co-cultures was measured with ELISA. Mean concentration \pm SEM from 5 to 6 $\mathrm{CD} 1 \mathrm{c}^{+} \mathrm{DC}$ and $\mathrm{pDC}$ donors is depicted. c, d Intracellular IFN- $\gamma$ was measured in $\mathrm{CD}^{+}{ }^{+} \mathrm{CD} 11 \mathrm{c}^{-} \mathrm{BDCA}^{-}{ }^{-} \mathrm{T}$ cells cultured for 5 days either alone or with DCs stimulated with medium or IL-3, R848, or pR complexes. Results are depicted as the mean percentage IFN- $\gamma^{+}$ cells \pm SEM from 6 CD $1 c^{+}$DC and $\mathrm{pDC}$ donors (c) or as a representative figure (d). Wilcoxon matched-pair signed-rank tests were performed between indicated groups and are indicated NS (non-significant) by $*(p<0.05), * *(p<0.05)$, or
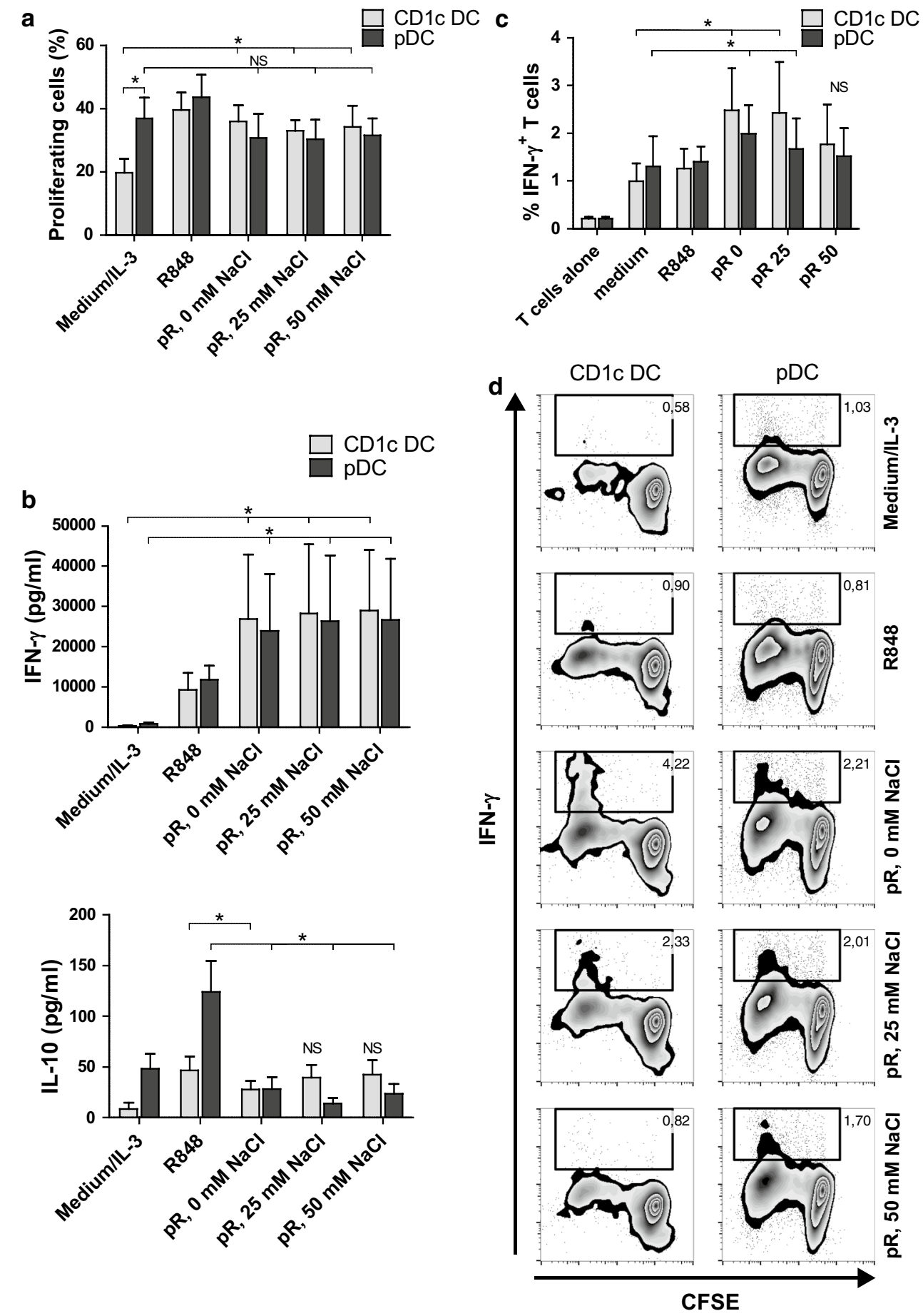

Fig. 2c), further demonstrating the importance of the endosomal route in response to protamine-RNA complexes.

\section{Protamine-RNA-stimulated DCs induce proliferation and activation of $T$ cells}

After characterizing the effects of protamine-RNA on primary DCs, the subsequent $\mathrm{T}$ cell response induced by activated DCs was investigated. Proliferation of CFSE-labeled
PBLs was measured in an allogeneic setting. The percentage of dividing $\mathrm{CD}^{+}$cells was determined 5 days after addition of protamine-RNA-activated DCs. As a positive control for proliferation, SEB was added (data not shown). R848- and protamine-RNA-treated $\mathrm{CD} 1 \mathrm{c}^{+}$DCs induced comparable proliferation of $\mathrm{T}$ cells, which was significantly higher than untreated DCs (Fig. 5a). Stimulated pDCs also induced a proliferative response in $\mathrm{T}$ cells comparable to IL-3-treated cells (Fig. 5a). 
To investigate the response of the stimulated $\mathrm{T}$ cells, the release of cytokines was measured. Supernatants were taken at day 2 of DC:PBL co-cultures, and IFN- $\gamma$, IL-10, and IL-5 were measured. Protamine-RNA-stimulated pDCs induced more IFN- $\gamma$ than IL-3-treated cells and in similar quantities as protamine-RNA-stimulated $\mathrm{CD} 1 \mathrm{c}^{+}$ DCs (Fig. 5b). In addition, the PBLs produced less IL-10 when co-cultured with protamine-RNA-stimulated pDCs than with IL-3 treated cells. For CD1c ${ }^{+}$DCs, the negative control induced only low levels of IFN- $\gamma$ and IL-10, while protamine-RNA-treated DCs stimulated elevated levels of both cytokines (Fig. 5b). No IL-5 secretion was detected (data not shown). This supports that $\mathrm{T}$ cells activated by protamine-RNA-stimulated DCs display Th1 characteristics and not a regulatory profile. To confirm this, the MLR experiment was repeated with purified allogeneic $\mathrm{T}$ cells, which were investigated for intracellular IFN- $\gamma$ production (Fig. 5c, d). T cells co-cultured with DCs activated by the smaller complexes produced significantly more IFN- $\gamma$ than control cultures.

\section{Antigen-specific $\mathbf{T}$ cell responses are induced by protamine-RNA-stimulated DCs}

To test the ability of protamine-RNA-stimulated DC to present antigens to T cells, HLA-A0201 ${ }^{+}$DCs were pulsed with either gp100 $280-288$ short peptide or irrelevant peptide and subsequently cultured with Jurkat cells transfected with the TCR-v-beta14 receptor recognizing gp100 $280-288$ in the context of HLA-A0201 (Fig. 6). The Jurkat cells are activated upon recognition of the specific antigen, independent of co-stimulatory signals. A distinct upregulation of activation marker CD69 was detected in Jurkat cells cultured with gp100 $280-288$-pulsed DCs, while irrelevant peptide-pulsed DCs induced responses comparable to Jurkat cells cultured with the protamine-RNA complexes in the absence of DCs. Hence, protamine-RNA-treated pDCs and $\mathrm{CD} 1 \mathrm{c}^{+} \mathrm{DCs}$ both retain the ability to present specific antigens to $\mathrm{T}$ cells.

\section{Discussion}

Our research group has recently focused on developing immunotherapeutic strategies based on primary DC subsets, using different clinical activation protocols for $\mathrm{mDCs}$ and pDCs $[8,9]$. In the pDC trial, Frühsommer-meningoencephalitis (FSME) vaccine was used to activate the cells $[9,32]$, while unbeneficial responses were seen for $\mathrm{CD} 1 \mathrm{c}^{+}$ DCs treated with FSME. Instead, GM-CSF has been used to activate this DC population, which does not efficiently activate pDCs to produce type I IFNs (Schreibelt et al., manuscript in preparation) [8]. The activation status of DCs
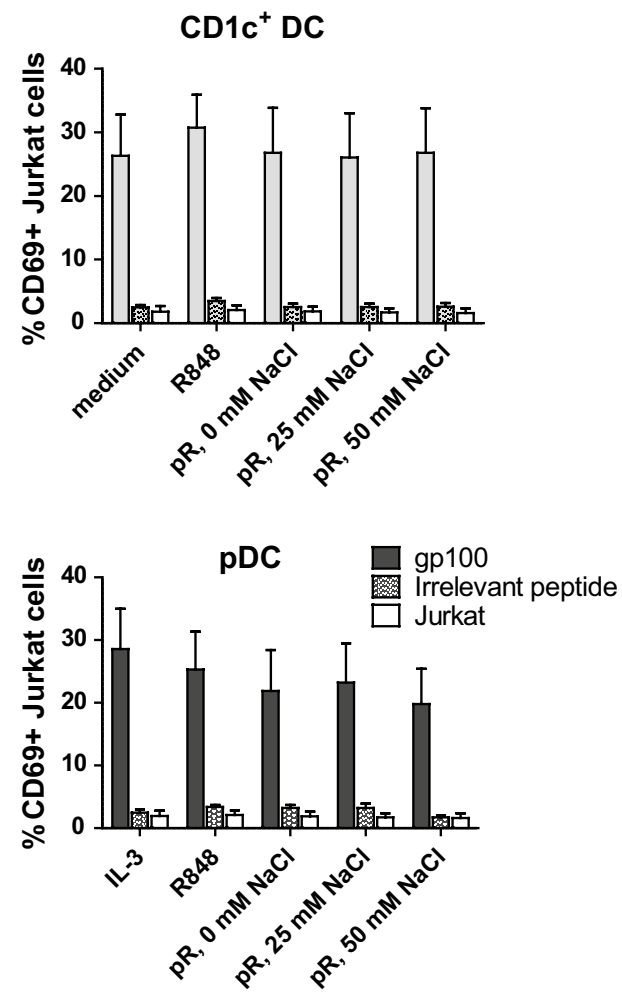

Fig. 6 Protamine-RNA-stimulated DCs can induce antigen-specific $\mathrm{T}$ cell responses. HLA-A0201 ${ }^{+}$DCs were pulsed with gp100 $280-288$ short peptide or irrelevant peptide, stimulated with protamine-RNA complexes (pR) formed in 0,25 , or $50 \mathrm{mM} \mathrm{NaCl}$, and co-cultured overnight with Jurkat cells expressing the TCR-v-beta14 receptor specific for the gp100 $280-288$ peptide in the context of HLA-A0201. The upregulation of CD69 on Jurkat cells was assayed with flow cytometry. The mean percentage of CD69 expression \pm SEM on Jurkat cells co-cultured with $6 \mathrm{CD}^{+} \mathrm{c}^{+} \mathrm{DC}$ and $\mathrm{pDC}$ donors is depicted

is an important factor for the subsequent adaptive immune responses. To induce full activation of DCs, signaling via PRRs such as TLRs is necessary [3, 33]. Although a vast number of TLR ligands have been developed, only a few are approved for clinical use. Currently, there is no TLR ligand available that can be used to activate both $\mathrm{mDCs}$ and $\mathrm{pDCs}$ which is produced according to good manufactoring practice (GMP) [18]. Therefore, we have used the clinical grade reagents protamine and mRNA to compile a TLR7/8 ligand with the ability to activate both pDCs and CD1c ${ }^{+}$DCs.

The immunopotent effect of ssRNA complexed to cationic proteins has previously been described [19, 20, 34], and the ionic content of the solution in which the complexes are formed has shown to affect their features and size [26]. Here, we have investigated the stimulatory effect of protamine-RNA complexes formed either in water or in increasing salt concentrations. Water or low salt concentrations formed smaller complexes, while high salt concentrations mediated formation of complexes larger than $500 \mathrm{~nm}$. When adding these complexes to 
primary pDCs and CD1c ${ }^{+}$DCs, the two subsets responded differently. All three complex formulations could stimulate $\mathrm{CD} 1 \mathrm{c}^{+} \mathrm{DCs}$ to upregulate maturation markers, $\mathrm{MHC}$ complexes, and pro-inflammatory cytokine production, although highest responses were seen with the larger complexes. Oppositely, pDCs fully matured after addition of the smaller complexes and not consistently with the complexes formed in high salt concentrations. This might be due to the inability of pDCs to efficiently engulf larger particles [27]. Indeed, when comparing the ability to bind and take up protamine-RNA complexes, pDCs associated significantly better with smaller complexes than with the large ones, while $\mathrm{CD} 1 \mathrm{c}^{+} \mathrm{DCs}$ associated with the different complexes equally. However, pDCs did associate with the large complexes, indicating that the binding and uptake is not the only factor regulating the cellular responses toward the complexes. For instance, the larger protamine-RNA complexes might be stronger ligands for TLR8, while smaller complexes are more efficient for TLR7 stimulation. This phenomenon has previously been described for synthetic TLR7/8 ligands [35, 36]. Furthermore, a difference in proteolytic cleavage between TLR7 and TLR8 was recently demonstrated [37]. In addition, the observed shift from a type I IFN-mediated response toward a NFkB-driven response has been reported to differentiate the responses mediated by TLR 7 and TLR 8 activation [36]. Although positive responses were detected for all three types of complexes, the TLR8 expressing HEK cell line responded strongest to the largest ones. Nevertheless, despite weaker responses, pDCs treated with protamine-RNA complexes formed in high salt concentration were still viable without extra addition of IL-3, which is needed for the long-term culturing of nonstimulated pDCs [28]. This indicates that even the larger complexes have the ability to provide a survival signal, but not necessarily fully activate pDCs. The decrease in pDC viability upon inhibition of endosomal acidification further supports this hypothesis.

To act as an effective adjuvant, a functional activation of relevant adaptive responses must be induced by DC treated with the stimulus. Protamine-RNA-stimulated DCs indeed induced proliferation of $\mathrm{T}$ cells. For $\mathrm{CD} 1 \mathrm{c}^{+} \mathrm{DCs}$, a significant difference was observed between unstimulated and stimulated DCs. Addition of the survival factor IL-3 to pDCs resulted in a high proliferation of PBLs, most likely due to an IL-3-induced upregulation of antigenpresenting molecules. We therefore investigated the activation of the co-cultured cells to determine what kind of adaptive response protamine-RNA-treated DCs induced. An increase in IFN- $\gamma$ production could be detected in both $\mathrm{CD} 1 \mathrm{c}^{+} \mathrm{DC}$ and $\mathrm{pDC}$ co-cultures, where $\mathrm{T}$ cells stimulated with protamine-RNA-treated DCs produced the highest levels of the cytokine.
In addition to inducing IFN- $\gamma$-producing $\mathrm{T}$ cells, an antigen-specific immune response must also be induced by the activated DCs. In our vaccination setting, stimulated DCs are pulsed externally with peptide antigens $[8,9,38]$. Protamine-RNA-treated DCs induced an antigen-specific response when pulsed with the gp100 $280-288$ HLA-A0201-binding peptide. IL-3-treated pDCs gave stronger results than both protamine-RNA complexes and R848 treatment, probably due to the elevated expression of antigen-presenting molecules, and it should be noted that this assay is not dependent on the activation status of the APC but rather on their ability to present peptide antigens.

To conclude, protamine-RNA complexes have the ability to induce maturation of pDCs and $\mathrm{CD} 1 \mathrm{c}^{+} \mathrm{DCs}$ via endosomal-dependent pathways, most likely via ssRNA-mediated activation of TLR7 and TLR8. For CD1 ${ }^{+}$DCs, the highest responses were observed with complexes of larger size, but significant upregulation of maturation markers, MHC molecules, and pro-inflammatory cytokines was detected also for the smaller complexes. Importantly, protamine-RNA complexes induced release of the Th1-skewing cytokine IL12 p70 from $\mathrm{CD} 1 \mathrm{c}^{+}$DCs, making the stimulus highly interesting when an anti-cancer response is desired. Also pDCs responded to protamine-RNA complexes, but for this subset smaller complexes, formed in water or low salt concentrations, induced the strongest maturation as well as IFN- $\alpha$ production. Taken together, protamine-RNA complexes pose as an interesting adjuvant that can be GMP produced and used for activation of primary DCs in cell-based immunotherapy. Depending on the protocol, large complexes can be used to activate $\mathrm{CD} 1 \mathrm{c}^{+} \mathrm{DCs}$, while small complexes are suitable to stimulate pDCs. Since the complexes are able to activate both $\mathrm{CD} 1 \mathrm{c}^{+}$DCs and pDCs, it also opens for the possibility of using protamine-RNA as a stimulus in a vaccine consisting of the two DC subsets together. Then the smaller complexes, with the ability to activate both pDCs and $\mathrm{CD} 1 \mathrm{c}^{+}$DCs, are recommended. High levels of IFN- $\alpha$ have been shown to activate cytotoxic responses in natural killer cells [39, 40], but have also been implemented in pDC:mDC cross-talk and Th1 responses [15, 41, 42]. The most prominent Th1-skewing cytokine, IL-12p70, is secreted by protamine-RNA-treated $\mathrm{CD} 1 \mathrm{c}^{+}$DCs. The combination of IFN- $\alpha$ and IL-12p70 derived from protamine-RNA-stimulated pDCs and $\mathrm{mDCs}$ is a potent and multifaceted immunotherapy.

Acknowledgments This work was supported by the Swedish Research Council, the Netherlands Organization for Scientific Research (NWO-Vici 91814655, NWO-Veni 86313024, and NWOZonMW 95103002), and a Radboudumc PhD grant.

\section{Compliance with ethical standards}

Conflict of interest The authors declare no conflicts of interest. 
Open Access This article is distributed under the terms of the Creative Commons Attribution 4.0 International License (http://creativecommons.org/licenses/by/4.0/), which permits unrestricted use, distribution, and reproduction in any medium, provided you give appropriate credit to the original author(s) and the source, provide a link to the Creative Commons license, and indicate if changes were made.

\section{References}

1. Boltjes A, van Wijk F (2014) Human dendritic cell functional specialization in steady-state and inflammation. Front Immunol 5:131. doi:10.3389/fimmu.2014.00131

2. Palucka K, Banchereau J (2013) Human dendritic cell subsets in vaccination. Curr Opin Immunol 25(3):396-402. doi:10.1016/j. coi.2013.05.001

3. Joffre O, Nolte MA, Sporri R, Reis e Sousa C (2009) Inflammatory signals in dendritic cell activation and the induction of adaptive immunity. Immunol Rev 227(1):234-247. doi:10.1111/j.1600-065X.2008.00718.x

4. Palm NW, Medzhitov R (2009) Pattern recognition receptors and control of adaptive immunity. Immunol Rev 227(1):221-233. doi:10.1111/j.1600-065X.2008.00731.x

5. Kawai T, Akira S (2010) The role of pattern-recognition receptors in innate immunity: update on Toll-like receptors. Nat Immunol 11(5):373-384. doi:10.1038/ni.1863

6. Figdor CG, de Vries IJ, Lesterhuis WJ, Melief CJ (2004) Dendritic cell immunotherapy: mapping the way. Nat Med 10(5):475-480. doi:10.1038/nm1039

7. Nestle FO, Farkas A, Conrad C (2005) Dendritic-cell-based therapeutic vaccination against cancer. Curr Opin Immunol 17(2):163-169. doi:10.1016/j.coi.2005.02.003

8. Wimmers F, Schreibelt G, Sköld AE, Figdor CG, De Vries IJ (2014) Paradigm shift in dendritic cell-based immunotherapy: from in vitro generated monocyte-derived DCs to naturally circulating DC subsets. Front Immunol 5:165. doi:10.3389/ fimmu.2014.00165

9. Tel J, Aarntzen EH, Baba T, Schreibelt G, Schulte BM, BenitezRibas D, Boerman OC, Croockewit S, Oyen WJ, van Rossum M, Winkels G, Coulie PG, Punt CJ, Figdor CG, de Vries IJ (2013) Natural human plasmacytoid dendritic cells induce antigenspecific T-cell responses in melanoma patients. Cancer Res 73(3):1063-1075. doi:10.1158/0008-5472.CAN-12-2583

10. Mazzoni A, Segal DM (2004) Controlling the Toll road to dendritic cell polarization. J Leukoc Biol 75(5):721-730. doi:10.1189/jlb.1003482

11. de Jong EC, Smits HH, Kapsenberg ML (2005) Dendritic cellmediated $\mathrm{T}$ cell polarization. Springer Semin Immunopathol 26(3):289-307. doi:10.1007/s00281-004-0167-1

12. Liu YJ (2001) Dendritic cell subsets and lineages, and their functions in innate and adaptive immunity. Cell 106(3):259-262

13. Schreibelt G, Tel J, Sliepen KH, Benitez-Ribas D, Figdor CG, Adema GJ, de Vries IJ (2010) Toll-like receptor expression and function in human dendritic cell subsets: implications for dendritic cell-based anti-cancer immunotherapy. Cancer Immunol Immunother 59(10):1573-1582. doi:10.1007/ s00262-010-0833-1

14. Sköld AE, Hasan M, Vargas L, Saidi H, Bosquet N, Le Grand R, Smith CI, Spetz AL (2012) Single-stranded DNA oligonucleotides inhibit TLR3-mediated responses in human monocytederived dendritic cells and in vivo in cynomolgus macaques. Blood 120(4):768-777. doi:10.1182/blood-2011-12-397778

15. Bakdash G, Schreurs I, Schreibelt G, Tel J (2014) Crosstalk between dendritic cell subsets and implications for dendritic cell-based anticancer immunotherapy. Expert Rev Clin Immunol 10(7):915-926. doi:10.1586/1744666X.2014.912561

16. Heil F, Hemmi H, Hochrein H, Ampenberger F, Kirschning C, Akira S, Lipford G, Wagner H, Bauer S (2004) Species-specific recognition of single-stranded RNA via toll-like receptor 7 and 8. Science 303(5663):1526-1529. doi:10.1126/science.1093620

17. Scheel B, Braedel S, Probst J, Carralot JP, Wagner H, Schild H, Jung G, Rammensee HG, Pascolo S (2004) Immunostimulating capacities of stabilized RNA molecules. Eur J Immunol 34(2):537-547. doi:10.1002/eji.200324198

18. Vasilakos JP, Tomai MA (2013) The use of Toll-like receptor 7/8 agonists as vaccine adjuvants. Expert Rev Vaccines 12(7):809819. doi:10.1586/14760584.2013.811208

19. Scheel B, Teufel R, Probst J, Carralot JP, Geginat J, Radsak M, Jarrossay D, Wagner H, Jung G, Rammensee HG, Hoerr I, Pascolo S (2005) Toll-like receptor-dependent activation of several human blood cell types by protamine-condensed mRNA. Eur J Immunol 35(5):1557-1566. doi:10.1002/eji.200425656

20. Fotin-Mleczek M, Duchardt KM, Lorenz C, Pfeiffer R, OjkicZrna S, Probst J, Kallen KJ (2011) Messenger RNA-based vaccines with dual activity induce balanced TLR-7 dependent adaptive immune responses and provide antitumor activity. J Immunother 34(1):1-15. doi:10.1097/CJI.0b013e3181f7dbe8

21. Hoerr I, Obst R, Rammensee HG, Jung G (2000) In vivo application of RNA leads to induction of specific cytotoxic T lymphocytes and antibodies. Eur J Immunol 30(1):1-7. doi:10.1002/15214141(200001)30:1<1::AID-IMMU1>3.0.CO;2-\#

22. Schaft N, Dorrie J, Muller I, Beck V, Baumann S, Schunder T, Kampgen E, Schuler G (2006) A new way to generate cytolytic tumor-specific $\mathrm{T}$ cells: electroporation of RNA coding for a $\mathrm{T}$ cell receptor into $\mathrm{T}$ lymphocytes. Cancer Immunol Immunother 55(9):1132-1141. doi:10.1007/s00262-005-0098-2

23. Schreibelt G, Benitez-Ribas D, Schuurhuis D, Lambeck AJ, van Hout-Kuijer M, Schaft N, Punt CJ, Figdor CG, Adema GJ, de Vries IJ (2010) Commonly used prophylactic vaccines as an alternative for synthetically produced TLR ligands to mature monocyte-derived dendritic cells. Blood 116(4):564-574. doi:10.1182/blood-2009-11-251884

24. Billiau A, Buckler CE, Dianzani F, Uhlendorf C, Baron S (1969) Induction of the interferon mechanism by single-stranded RNA: potentiation by polybasic substances. Proc Soc Exp Biol Med 132(2):790-796

25. Morille M, Passirani C, Vonarbourg A, Clavreul A, Benoit JP (2008) Progress in developing cationic vectors for non-viral systemic gene therapy against cancer. Biomaterials 29(2425):3477-3496. doi:10.1016/j.biomaterials.2008.04.036

26. Rettig L, Haen SP, Bittermann AG, von Boehmer L, Curioni A, Kramer SD, Knuth A, Pascolo S (2010) Particle size and activation threshold: a new dimension of danger signaling. Blood 115(22):4533-4541. doi:10.1182/blood-2009-11-247817

27. Tel J, Schreibelt G, Sittig SP, Mathan TS, Buschow SI, Cruz LJ, Lambeck AJ, Figdor CG, de Vries IJ (2013) Human plasmacytoid dendritic cells efficiently cross-present exogenous Ags to CD8+ $\mathrm{T}$ cells despite lower Ag uptake than myeloid dendritic cell subsets. Blood 121(3):459-467. doi:10.1182/ blood-2012-06-435644

28. Colonna M, Trinchieri G, Liu YJ (2004) Plasmacytoid dendritic cells in immunity. Nat Immunol 5(12):1219-1226. doi:10.1038/ ni1141

29. Kreiter S, Selmi A, Diken M, Koslowski M, Britten CM, Huber C, Tureci O, Sahin U (2010) Intranodal vaccination with naked antigen-encoding RNA elicits potent prophylactic and therapeutic antitumoral immunity. Cancer Res 70(22):9031-9040. doi:10.1158/0008-5472.CAN-10-0699

30. Hontelez S, Ansems M, Karthaus N, Zuidscherwoude M, Looman MW, Triantis V, Adema GJ (2012) Dendritic 
cell-specific transcript: dendritic cell marker and regulator of TLR-induced cytokine production. J Immunol 189(1):138-145. doi:10.4049/jimmunol.1103709

31. Lee J, Chuang TH, Redecke V, She L, Pitha PM, Carson DA, Raz E, Cottam HB (2003) Molecular basis for the immunostimulatory activity of guanine nucleoside analogs: activation of Tolllike receptor 7. Proc Natl Acad Sci USA 100(11):6646-6651. doi:10.1073/pnas.0631696100

32. de Vries IJ, Tel J, Benitez-Ribas D, Torensma R, Figdor CG (2011) Prophylactic vaccines mimic synthetic CpG oligonucleotides in their ability to modulate immune responses. Mol Immunol 48(6-7):810-817. doi:10.1016/j.molimm.2010.12.022

33. de Vries IJ, Lesterhuis WJ, Scharenborg NM, Engelen LP, Ruiter DJ, Gerritsen MJ, Croockewit S, Britten CM, Torensma R, Adema GJ, Figdor CG, Punt CJ (2003) Maturation of dendritic cells is a prerequisite for inducing immune responses in advanced melanoma patients. Clin Cancer Res 9(14):5091-5100

34. Ganguly D, Chamilos G, Lande R, Gregorio J, Meller S, Facchinetti V, Homey B, Barrat FJ, Zal T, Gilliet M (2009) SelfRNA-antimicrobial peptide complexes activate human dendritic cells through TLR7 and TLR8. J Exp Med 206(9):1983-1994. doi:10.1084/jem.20090480

35. Yoo E, Salunke DB, Sil D, Guo X, Salyer AC, Hermanson AR, Kumar M, Malladi SS, Balakrishna R, Thompson WH, Tanji H, Ohto U, Shimizu T, David SA (2014) Determinants of activity at human toll-like receptors 7 and 8: quantitative structure-activity relationship (QSAR) of diverse heterocyclic scaffolds. J Med Chem 57(19):7955-7970. doi:10.1021/jm500744f

36. Gorden KB, Gorski KS, Gibson SJ, Kedl RM, Kieper WC, Qiu X, Tomai MA, Alkan SS, Vasilakos JP (2005) Synthetic TLR agonists reveal functional differences between human TLR7 and TLR8. J Immunol 174(3):1259-1268
37. Ishii N, Funami K, Tatematsu M, Seya T, Matsumoto M (2014) Endosomal localization of TLR8 confers distinctive proteolytic processing on human myeloid cells. J Immunol 193(10):5118 5128. doi:10.4049/jimmunol.1401375

38. Lesterhuis WJ, Schreibelt G, Scharenborg NM, Brouwer HM, Gerritsen MJ, Croockewit S, Coulie PG, Torensma R, Adema GJ, Figdor CG, de Vries IJ, Punt CJ (2011) Wild-type and modified gp100 peptide-pulsed dendritic cell vaccination of advanced melanoma patients can lead to long-term clinical responses independent of the peptide used. Cancer Immunol Immunother 60(2):249-260. doi:10.1007/s00262-010-0942-x

39. Romagnani C, Della Chiesa M, Kohler S, Moewes B, Radbruch A, Moretta L, Moretta A, Thiel A (2005) Activation of human NK cells by plasmacytoid dendritic cells and its modulation by CD4+ T helper cells and CD4+ CD25hi T regulatory cells. Eur J Immunol 35(8):2452-2458. doi:10.1002/eji.200526069

40. van Beek JJ, Wimmers F, Hato SV, de Vries IJ, Sköld AE (2014) Dendritic cell cross talk with innate and innate-like effector cells in antitumor immunity: implications for DC vaccination. Crit Rev Immunol 34(6):517-536

41. Fonteneau JF, Larsson M, Beignon AS, McKenna K, Dasilva I, Amara A, Liu YJ, Lifson JD, Littman DR, Bhardwaj N (2004) Human immunodeficiency virus type 1 activates plasmacytoid dendritic cells and concomitantly induces the bystander maturation of myeloid dendritic cells. J Virol 78(10):5223-5232

42. Starbeck-Miller GR, Xue HH, Harty JT (2014) IL-12 and type I interferon prolong the division of activated CD8 T cells by maintaining high-affinity IL-2 signaling in vivo. J Exp Med 211(1):105-120. doi:10.1084/jem.20130901 